\begin{tabular}{|c|c|}
\hline 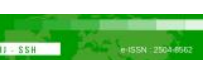 & Malaysian Journal of Social Sciences and Humanities (MJSSH) \\
\hline Malaysian Journal of & Volume 6, Issue 6, June 2021 \\
\hline (MJ-sSH) & e-ISSN : 2504-8562 \\
\hline & $\begin{array}{l}\text { Journal home page: } \\
\text { www.msocialsciences.com }\end{array}$ \\
\hline
\end{tabular}

\title{
Perspectives of Practitioners on the Green Infrastructure in Mukalla City, Yemen
}

\author{
Omar Ali Ahmed Bagazi', M Zainora Asmawi ${ }^{1}$, Lukman Hakim Mahamod', \\ Syakir Amir Ab Rahman¹, Abdul Razak Abd Aziz ${ }^{2}$ \\ 1Department of Urban and Regional Planning, Kulliyyah of Architecture and Environmental Design, \\ International Islamic University Malaysia \\ ${ }^{2}$ Faculty of Architecture and Built Environment, City University Malaysia \\ Correspondence: M Zainora Asmawi (zainora@iium.edu.my)
}

\begin{abstract}
Green infrastructure (GI) is a new term that aims to accomplish sustainable development. It is a platform to achieve a balance between environmental preservation and urban development and achieve economic, social and environmental benefits. However, many countries are suffering from a lack of investment in GI benefits, especially developing countries. Therefore, this study aims to assess the level of attitude among practitioners through assessing their willingness to invest in GI benefits. A quantitative research approach and the questionnaire were designed, containing 17 main benefits of GI to achieve the aim of this study. The questionnaires were distributed manually to the agencies of planning and designing of urban area in Mukalla city. The total number of completed questionnaires entered into this study was 82- the SPSS program approved for results analysis. Relative important index (RII) was used to rank the items, means $(\overline{\mathrm{X}})$ was used to assess the level of attitude among practitioners. Pearson's Chi-square test $(\chi 2)$ was used to explore the impact of the demographic factors of practitioners on their attitude. In contrast, multiple linear regression was used to predict the relation between attitude and demographic factors. Firstly, the overall means $(\overline{\mathrm{X}})$ revealed that the GI attitude among practitioners in Mukalla city was positive. Secondly, the cross-tabulation revealed that all-male, old and non-government practitioners having a positive attitude, similarly all highly experienced and postgraduate practitioners also had a positive attitude. Pearson's Chi-square test $\left(\chi^{2}\right)$ showed that experience has no significant influence on GI's economic, social and environmental benefits. Thirdly, multiple linear regression showed that gender and education of practitioners contribute positively toward increasing the level of attitude among practitioners in Mukalla city.
\end{abstract}

Keywords: Green infrastructure, economy, social, environment, practitioners

\section{Introduction}

The world is getting more civilized. More than half of the world's population lives in cities. By 2050, the percentage of people living in an urban area will increase to $66 \%$ (UN, 2011). Environmental problems are growing, especially in areas of population growth and rapid urbanisation. As it is known, the ecosystem provides service to biodiversity, benefits human society, and contributes to the economy (Kumar, 2010). Despite all of the ecosystem's benefits, the relation between humans and ecosystems is still not sustainable, especially in urban areas (Randolph, 2004). The negative human impact on the environment became evident after the Industrial Revolution. The earth's temperature increased because of the accumulation of warm gas in the atmosphere (MacKinnon et al., 2008). Human activity related to 
the industrial sector and urbanisation has significantly increased, this resulted in a negative impact on the quality of the air, the water quantity and in destroying the biodiversity in cities (some animals and birds have disappeared and many green areas destroyed) (Chibrik et al., 2016). According to the mentioned indicators, it is clear that humans dominate the planet and are threatening other species life (Vitousek et al., 1997).

The establishment of green infrastructure (GI) contributes positively to enhancing ecosystem services, especially in developed urban areas (Du Toit et al., 2018; Li et al., 2016; Youngquist, 2009). GI is a planning approach designed to create a network of green spaces that benefit humans, achieve biodiversity and fight fragmentation. GI would enhance human well-being and human health by providing social, economic, and environmental benefits and providing places for entertainment everywhere. GI would also help the environment recover from its current problem by helping to decrease the temperature of the atmosphere and absorbing the pollutants. The ecosystem will retain its biological diversity (Benedict \& McMahon, 2002).

In our time, the demands of GI are increasing. Many countries have recognised it. The United States has incorporated the GI development policy into the legislative framework because they believe that the GI policy serves humanity in particular and the climate and the environment (Roe \& Mell, 2013). Several types of research have been conducted on GI planning in developed countries, while very little has been done in the developing ones (Girma et al., 2019).

\section{Literature Review}

\section{Benefits of Green Infrastructure}

Urban green infrastructure (open space, landscapes, natural area with their green components) is essential in metropolitan cities (Gallet, 2011). Integrating urban green infrastructure (UGI) with Integrated storm water management (ISMA) provides the best solutions to mitigate the consequences of rapid urbanisation, climate change and lack of sustainable development (Vasilevska \& Vasilevska, 2019). Figure 1 shows that interventions of GI through its principles and components lead to the activation of ecosystem services and biological diversity. The activation of ecosystem services and biological diversity brings multi functionality (benefits for the economic, social and environmental levels). All benefits are primarily aimed at achieving human well-being. For more function and benefits of GI, see Table 1.

Figure 1: Stages of Activate of Green Infrastructure Benefits

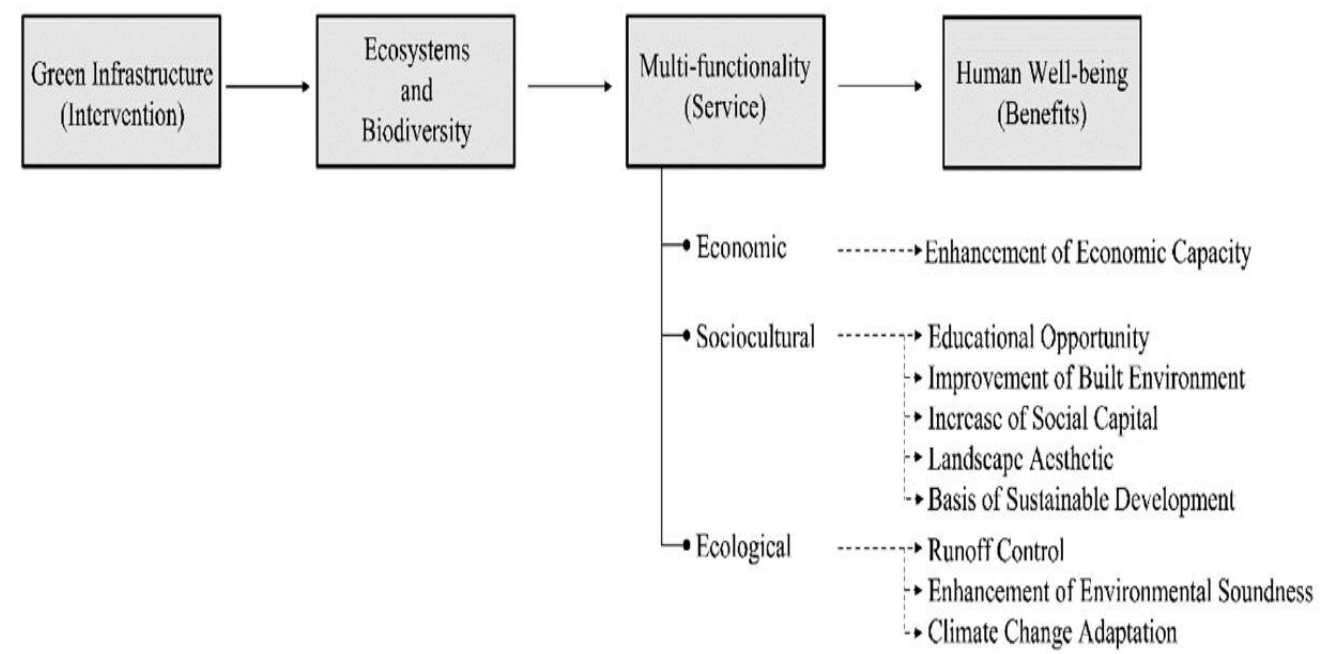


Table 1: Green Infrastructure Functionality and Type of Benefits

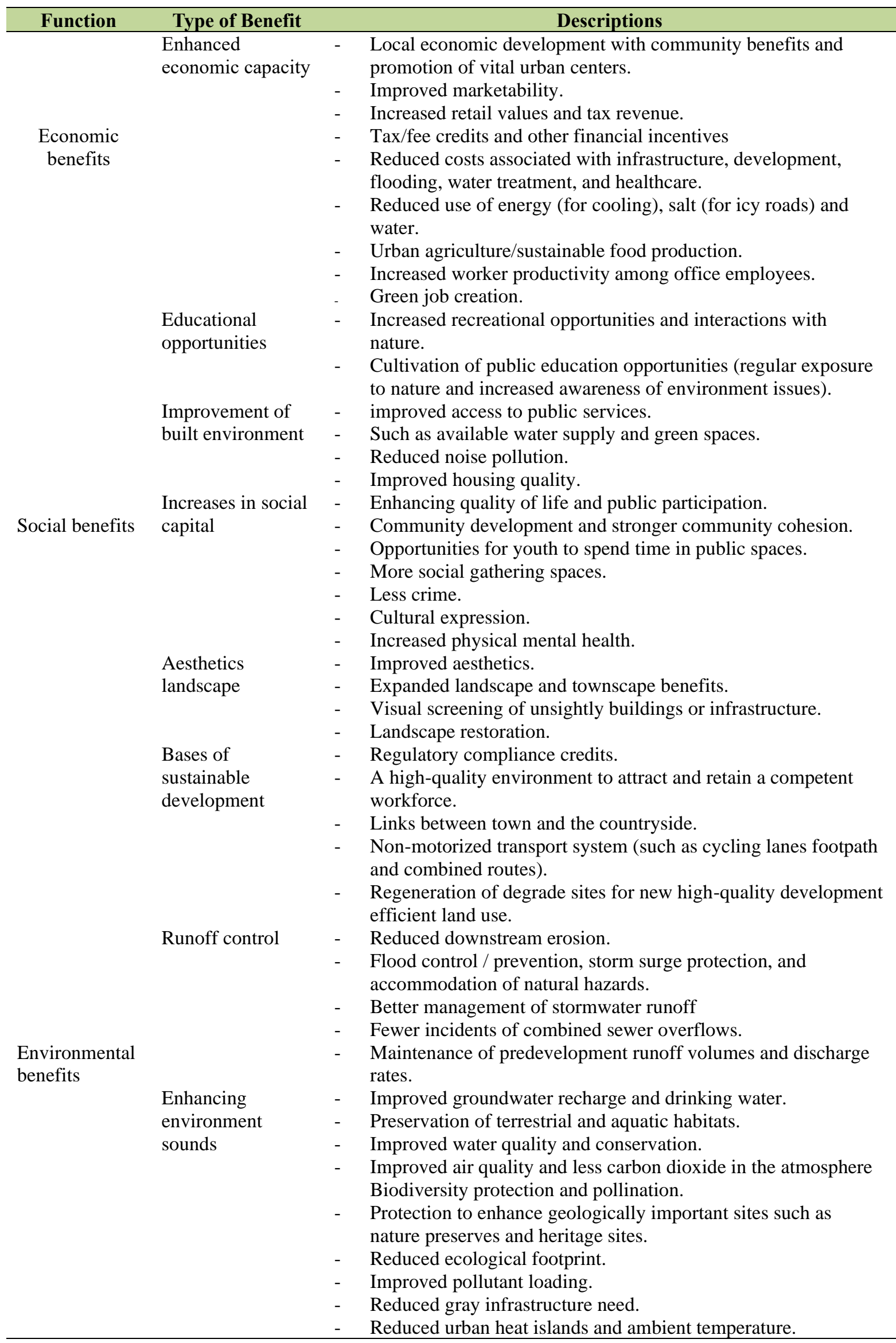




\begin{tabular}{lll}
\hline & - & Resilient infrastructure and climate change adaptation \\
Climate change & - & Reduced gray infrastructure need. \\
adaptation & - & Reduced urban heat islands and ambient temperature. \\
& - & Resilient infrastructure and climate change adaptation \\
& & mitigation.
\end{tabular}

Source: Cirillo \& Podolsky (2012); Dietz (2007); Foster et al. (2011); Gallet (2011); Lovell \& Taylor (2013); SG (2012); Xiao et al. (2018); Zimmerman et al. (2010).

\section{Economic Benefits}

The development of GI can stimulate a sustainable local economy. GI plays a significant role in the economic dimensions of urban development (Benedict \& McMahon, 2002). GI has so many financial roles. The first economic role of GI in increasing the market price of land, home and rents are clear. A home that GI surrounds usually has high values (high market price). For example, a study conducted in three Dutch cities showed that houses were up to $28 \%$ more expensive when they offered a pleasant view (Luttik, 2000). Second, the economic role of GI networks in creating Attraction aesthetics place for Tourism has evidence. A study conducted in the US showed that tourists are willing to pay fees for visiting places with GI elements (Majumdar et al., 2011). Moreover, a study conducted by Deng et al. (2010) showed that GI adds a scene of beauty to the urban area and is considered a significant factor in attracting tourists.

Third, the economic role of GI networks in disease reduction has a piece of evidence also. Regular contact with GI in cities encourage people to do physical activities. Physical activities enhance the overall health, which led to reduces the cost of disease treatment. An example of a study of ten cities in the US revealed that GI was estimated to reduce disease treatment cost by 4,000,000 USD to 69,400,000 USD per year (Wolf \& Robbins, 2015). Fourth the economic role of GI in disaster prevention is clear. GI elements such as green roof can retain or slow the flow of precipitation reaching the ground. This action leads to reduce the risk of flooding costs. Furthermore, a study conducted in Beijing showed that The integrated GI configuration could reduce the total runoff between $100 \%$ to $85 \%$ and peak flow $100 \%$ to $92 \%$ (Liu et al., 2014). Fifth, the economic role of GI in providing saleable goods is clear. According to Poe et al. (2013), GI provides a variety of medicines, many kinds of local food and materials beneficial for the well-being of urban residents.

The sixth economic role of GI networks in reduced energy use (for cooling) is prominent. The provision of shades through trees is crucial in providing thermal comfort for humans, especially on hot summer days ( $\mathrm{Li}$ et al., 2018). Trees contribute to improving the short and long term air temperature. The impact of trees on the short-term is clear and compelling. The temperature near trees is not the same as the air temperature where there are no trees in the same region. It is about 3 degrees Celsius less than there are no trees (Alabi \& Christian, 2013). Trees reduce the consumption of electric energy used in the operation of air-cooling systems (Demuzere et al., 2014). For example, a study showed the ability of trees to reduce the energy demands of houses in the US by $10 \%-15 \%$ annual cooling demand.

\section{Social Benefits}

GI has so many social benefits. One of them that GI plays a significant role in enhancing the overall health of humans. Scientific literature proves that GI can positively affect human health and well-being (Tzoulas et al., 2007). People living near green spaces are healthier than people living far from green areas. People in urban areas demand green spaces to live in a healthy way (Maas et al., 2006). Now, people are looking at green spaces as a vital feature to enhance mental health, such as recovery from mental fatigue (Beyer et al., 2014). Stress causes many diseases such as sleep loss, high blood pursues, diabetes and stroke (Leavitt, 2007). Many people see GI as a way of relieving the stresses of life and work. In addition, according to Maas et al. (2006), it can be a source of relaxation and entertainment. Spending time and doing physical activity, for example, walking, has GI element contribute to relieving the stresses (Hartig et al., 2011). 
Furthermore, GI enhances social cohesion. Social cohesion means shares cooperates and interacts between the people within one society. Studies by Kemperman and Timmermans (2014) and Peters et al. (2010), suggested that there is strong evidence that shows that GI contributes to improving social cohesion

\section{Environmental Benefits}

Rapid urbanisation causes a change in land use. This change causes loss of vegetation, which in return will trigger several Environment problems such as floods, climate change, high temperature and an increase of pollutants in air, water and soil. Luan et al. (2019) opined that GI is a network of decentralized practices with several examples, including green roofs, trees, rainforests and docks. This practice contributes to infiltrating the water into either special tanks or the ground (Asadian \& Weiler, 2009). GI practices also contribute to air quality improvement and the gases emission reduction (Gonzalez-Meler et al., 2016). Trees play a crucial role in clearing the air from suspended particles and other contaminants. We need to choose the right type of trees that are friendly to the environment, and it is required to be put in the right place to help overcome environmental pollution problems (Chakre, 2006). Having trees in a city is the least expensive way and practical at the same time to clean the air and improving its quality, as suggested by Jeanjean et al. (2017). For instance, the overall amount of carbon sequestered by urban trees has been estimated to be at 1\%-3\% of cities' annual greenhouse gas emissions. Air purification from gaseous pollutants in the GI area depends mainly on two ways: 1 reducing greenhouse gas emissions by encouraging walking and cycling. This action leads to decreasing the number of cars considered the primary source of greenhouse gas emissions. 2 Increasing the distance between the gas emission source and the receiver.

\section{Methodology}

\section{Study Area}

Hadhramaut is the largest governorate in Yemen, covering $161,749 \mathrm{~km}^{2}$ (Al Khulaidi, 2006). The study area (Mukalla city) is the capital of Hadhramaut governorate, which is located on the shores of the Arabian Sea in the southeast part of Yemen at longitude 49.10 degrees and latitude 14.33 degrees. A group of medium-rise mountains surrounds it in a curvature way. Furthermore, it has several valleys, which end up flowing to its coastal sea (Al-Alimi et al., 2013).

Figure 2: Location of Study Area (Mukalla City)

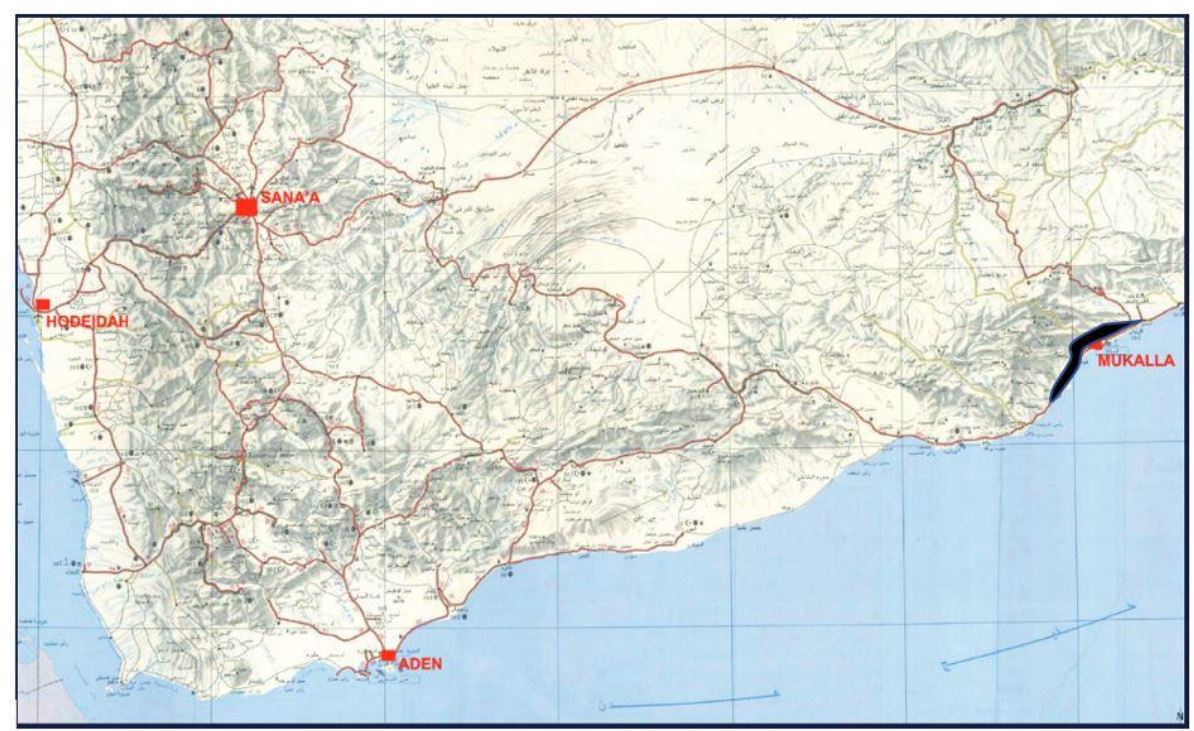

Source: Mukalla : Gateway to the Hadramout, n.d.) 
Figure 2 shows the location of Mukalla city, about the essential governorates of Yemen, which are Sana'a, Aden and Hodeida. Mukalla city is far away $(798,67 \mathrm{~km})$ from the capital, Sanaa. Mukalla city stretches 20 kilometres on both sides of the central zone east and west. the parts of Mukalla city are not joined together, so the line of urban development is disconnected. Instead, it is a group of not completely connected settlements along the coastline and the adjacent mountainous terrain. The city regions grow according to specific needs of the area and needs of the city as a whole ("Mukalla: Gateway to the Hadramout," n.d.). The town consists of three main zones: eastern zone, central zone, and western zone as shown in Figure 3.

Figure 3: The Main Zones of Study Area (Mukalla city)

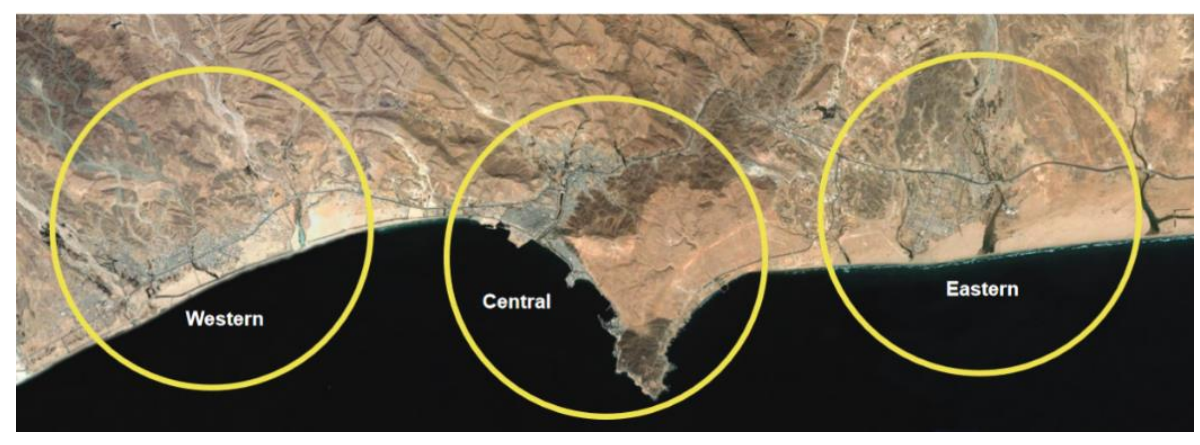

Source: Mukalla : Gateway to the Hadramout, n.d.

In terms of climate, the city of Mukalla is one of the coastal cities characterized by a high temperature in the summer and a relatively mild in winter (Al-Maashi, 1998). The average annual maximum temperature is $31.0^{\circ}$, while the average annual minimum temperature is: $25.0^{\circ}$. Similarly, Al-Mukalla is characterized by high relative humidity. Its humidity maximum rates are around $96 \%$ and its annual average $94 \%$, while its lowest monthly rates decrease to $56 \%$. The rain in Mukalla city is sporadic, but it goes very heavily when it rains and has a strong thunderstorm. The total annual average of rainfall is $72 \mathrm{~mm}$. In terms of population growth, the census conducted in 2004 showed that the population was 231,000 . The majority of $80 \%$ of the city's population is concentrated in the Center of the city. The growth was at a rate of $3 \%$. By 2025, it is expected that the number of people in the city will increase to approximately 530,000 .

\section{Primary Data}

Primary Data was collected using a questionnaire of 5-point Likert scale ( $1=$ Totally agree, $5=$ Totally disagree). The questionnaire was designed to contain 17 main benefits of GI. Data were analysed quantitatively using statistical analysis software, known as SPSS. Descriptive statistical methods such as frequencies, means, and percentages were used to assess practitioners' attitude toward GI benefits. The adopted scale to measure the level of attitude consists of three levels (positive, moderate and negative). In this regard, the score in the range of $0-2$ represents the negative level; the score in the range of $2.1-3$ represents the moderate level, and the score in the range of $3.1-5$ represents the positive level, respectively.

Pearson's Chi-square test $(\chi 2)$ was used to explore the influence of demographic factor (gender, age, type agency, experiences, and education) on the level of attitude of practitioners in Mukalla city. This test gives consistent results in three cases (demographic factors on economic attitude, social attitude and environment attitude). $\chi^{2}$ yield similar conclusions at any given usual level of confidence. In this research, we used $5 \%$ as our rejection limits. 


\section{Result}

In this study, attitude means practitioners' belief in the benefits and values of the GI concept. The practitioners' attitude toward the benefits and values of the GI concept was studied in four parts. The first part aims to assess the level of attitude among practitioners. The second part seeks to determine the types of attitude (economic, social, and environmental attitudes). The third part aims to explore the demographic factor that influences the attitude. The fourth part seeks to predict the level of attitude. The analysis for each element is given in the subsequent subsections.

\section{Practitioners' Profiles}

Ninety-six questionnaires were distributed in the two types of agencies (government and nongovernment agencies of planning and designing urban area) in Mukalla city Yemen. Eighty-five of the respondents returned the questionnaire. Eighty-two of the returned questionnaires were valid to use in the study ( $85.41 \%$ response rate). Table 2 presents the demographic information of practitioners. In terms of gender, the practitioners surveyed are primarily male.

Table 2: Demographic Information of Respondents

\begin{tabular}{lclcc}
\hline \multicolumn{1}{c}{ Demographic factors } & Code & \multicolumn{1}{c}{ Item } & N & \% \\
\hline Gender & M & Male & 63 & 76.80 \\
Age & F & Female & 19 & 23.20 \\
& AG1 & $24-39$ & 71 & 86.60 \\
Type of agencies & AG2 & $40-54$ & 11 & 13.40 \\
& GO & Government agencies & 27 & 32.90 \\
Experience years & PR & Private agencies & 55 & 67.10 \\
Educational qualification & EX1 & Less than 5 years & 75 & 91.50 \\
& EX2 & 5 to less than 10 & 7 & 08.50 \\
& ED1 & Graduate from high school & - & - \\
& ED2 & Graduate from technical & 5 & 06.10 \\
& & institute & 70 & 85.40 \\
& ED3 & Bachelor degree & 7 & 08.50 \\
\hline
\end{tabular}

Concerning age, the majority of practitioners $(86.60 \%)$ fall into the youth category (18 - 34 years). In terms of the type of (government or non-government), most practitioners $(67.10 \%)$ were employed in non-government planning and design agencies. In terms of experiences, most practitioners $(91.50 \%)$ were in the category of less experience. Finally, in term of education, the vast majority $(85.4 \%)$ of practitioners have a bachelor degree. In contrast, no one among practitioners has high school education that the private and government planning and design agencies do not employ practitioners with high school qualification only.

\section{Assessment of Green Infrastructure Benefits}

This part of the analysis uses RII and SD values to rank the items of attitude and $\bar{x}$ values to assess the levels of attitude items. The RII values were calculated for all attitude items (from BE1 to BE17 items) based on numerical scores obtained from the practitioners in Mukalla city. The attitude items were ranked based on the highest RII value (the highest RII, the highest rank, and vice versa). If two attitude items have the same RII value, the ranking will base on the lowest SD value. For example, as shown in Table 3, although BE3 and BE5 items of attitude have the same RII, the BE3 item was ranked higher than the BE5 item due to the lower SD value. 
DOI: https://doi.org/10.47405/mjssh.v6i6.809

Table 3: Level of Attitude on GI Concept Among Practitioners in Mukalla City by Mean

\begin{tabular}{|c|c|c|c|c|c|c|c|}
\hline & Code & Item & $\overline{\mathbf{x}}$ & SD & RII & Rank & Level \\
\hline \multirow[t]{7}{*}{ Economy } & BE1 & $\begin{array}{l}\text { Increasing the value } \\
\text { of residential and } \\
\text { commercial area }\end{array}$ & 3.84 & 1.14 & $76.8 \%$ & 12 & Positive \\
\hline & BE2 & $\begin{array}{l}\text { Creating Attraction } \\
\text { aesthetics place for } \\
\text { Tourism }\end{array}$ & 4.44 & 0.91 & $88.8 \%$ & 2 & Positive \\
\hline & BE3 & $\begin{array}{l}\text { Increasing employees' } \\
\text { performance }\end{array}$ & 3.90 & 1.02 & $78.0 \%$ & 10 & Positive \\
\hline & BE4 & $\begin{array}{l}\text { Contribute to disaster } \\
\text { prevention }\end{array}$ & 3.65 & 1.15 & $73.0 \%$ & 14 & Positive \\
\hline & BE5 & $\begin{array}{l}\text { Contributes to energy } \\
\text { saving }\end{array}$ & 3.90 & 1.15 & $78.0 \%$ & 11 & Positive \\
\hline & BE6 & $\begin{array}{l}\text { Contributes to disease } \\
\text { reduction }\end{array}$ & 4.01 & 1.07 & $80.2 \%$ & 8 & Positive \\
\hline & BE7 & $\begin{array}{l}\text { Contributes to Provide } \\
\text { marketable goods }\end{array}$ & 3.65 & 1.28 & $73.0 \%$ & 15 & Positive \\
\hline \multirow[t]{6}{*}{ Social } & BE8 & $\begin{array}{l}\text { Contributes to noise } \\
\text { reduction }\end{array}$ & 3.43 & 1.25 & $68.6 \%$ & 17 & Positive \\
\hline & BE9 & $\begin{array}{l}\text { Enhances the overall } \\
\text { health }\end{array}$ & 4.20 & 1.01 & $84.0 \%$ & 5 & Positive \\
\hline & BE10 & $\begin{array}{l}\text { Reduces life and work } \\
\text { stress }\end{array}$ & 4.48 & 0.85 & $89.6 \%$ & 1 & Positive \\
\hline & BE11 & $\begin{array}{l}\text { Promotes human well- } \\
\text { being. }\end{array}$ & 4.30 & 0.84 & $86.0 \%$ & 4 & Positive \\
\hline & BE12 & $\begin{array}{l}\text { Promotes communal } \\
\text { activities }\end{array}$ & 3.83 & 1.01 & $76.6 \%$ & 13 & Positive \\
\hline & BE13 & $\begin{array}{l}\text { Increases social } \\
\text { communication and } \\
\text { Community }\end{array}$ & 3.59 & 1.13 & $71.8 \%$ & 16 & Positive \\
\hline \multirow[t]{5}{*}{ Environment } & BE14 & $\begin{array}{l}\text { Improves local } \\
\text { climate elements }\end{array}$ & 4.16 & 1.06 & $83.2 \%$ & 6 & Positive \\
\hline & BE15 & $\begin{array}{l}\text { Provides Pollutants } \\
\text { filtration }\end{array}$ & 4.31 & 0.91 & $86.2 \%$ & 3 & Positive \\
\hline & BE16 & Enhances biodiversity & 4.07 & 1.00 & $81.4 \%$ & 7 & Positive \\
\hline & BE17 & $\begin{array}{l}\text { Promotes Nature } \\
\text { conservation }\end{array}$ & 3.91 & 1.19 & $78.2 \%$ & 9 & Positive \\
\hline & \multicolumn{2}{|c|}{ Overall } & 3.98 & & $79.6 \%$ & - & Positive \\
\hline
\end{tabular}

It is observed from Table 3 that the $\bar{x}$ value of the 17 items of attitude ranged between 3.43 and 4.48. that mean all the 17 items showed a positive level (all items > 3.1). The analysis concluded that the practitioner's Attitude toward GI benefits was positive at $\overline{\mathrm{x}}$ values equal to 3.98. The findings also indicate that the two highest items in rank were reduced life and work stress (RII=89.6\%). Based on this result, it is clear that the practitioners highly believe in GI's role in lowering life and work stress in Mukalla city. This indicates that practitioners have a strong belief in the Psychological benefit of GI. This result has confirmed the result obtained by Hansmann et al. (2007), Roe et al. (2013) and Thompson et al. (2012) strongly support the stress reduction theory, which is a widely accepted theory.

In terms of the second-highest benefit, which is creating an attraction aesthetics place for tourism, the result shows that the RII is $88.8 \%$. The result indicates that the practitioners in Mukalla city value the benefit of GI in enhancing the tourist sector. This result is supported by Rahman et al. (2013), which showed a strong relationship between tourism and GI benefits. At the same time, the lowest items in rank were Contributes to noise reduction (RII $=68.6 \%$ ). According to practitioners in Mukalla city, the 
role of GI in reducing noise is limited. This result confirms the results obtained by Rahman et al. (2013), which showed that reducing noise is the lowest benefits. There are only a tiny minority of professionals who believe that greening reduces city noise. The reason for this is that the benefit has not been practically studied and proven yet.

\section{Factors Influencing Benefits}

To explore the influence of demographic factor (gender, age, place of work, experience and education qualification) on the level of attitude (economic, social and ecological) among practitioners in Mukalla city, Cross-tabulation was made. Table 4 displays the calculated values of negative level, positive level and $\chi 2$ Value.

Table 4: Cross-tabulation of Practitioners' Attitude by Demographic Factors

\begin{tabular}{|c|c|c|c|c|c|c|c|}
\hline & \multicolumn{2}{|c|}{ Economy } & \multicolumn{2}{|c|}{ Social } & \multicolumn{2}{|c|}{ Environment } & \multirow[t]{2}{*}{ TOTAL } \\
\hline & Negative & Positive & Negative & Positive & Negative & Positive & \\
\hline & $\mathrm{N}(\%)$ & $\mathrm{N}(\%)$ & $\mathrm{N}(\%)$ & $\mathrm{N}(\%)$ & $\mathrm{N}(\%)$ & $\mathrm{N}(\%)$ & $\mathrm{N}(\%)$ \\
\hline \multicolumn{8}{|c|}{ (1) GENDER AND GI BENEFITS } \\
\hline Male & $\begin{array}{c}11 \\
(17.5 \%)\end{array}$ & $\begin{array}{c}52 \\
(82.5 \%)\end{array}$ & $5(7.9 \%)$ & $\begin{array}{c}58 \\
(92.1 \%)\end{array}$ & $\begin{array}{c}10 \\
(15.9 \%)\end{array}$ & $\begin{array}{c}53 \\
(84.1 \%)\end{array}$ & $\begin{array}{c}63 \\
(76.8 \%)\end{array}$ \\
\hline Female & $0(0 \%)$ & $\begin{array}{c}19 \\
(100 \%)\end{array}$ & $0(0 \%)$ & $19(100 \%)$ & $0(0 \%)$ & $\begin{array}{c}19 \\
(100 \%)\end{array}$ & $\begin{array}{c}19 \\
(23.2 \%)\end{array}$ \\
\hline TOTAL & $11(13.5 \%)$ & $\begin{array}{c}71 \\
(86.5 \%)\end{array}$ & $5(6.1 \%)$ & $\begin{array}{c}77 \\
(93.9 \%)\end{array}$ & $\begin{array}{c}10 \\
(12.2 \%)\end{array}$ & $\begin{array}{c}72 \\
(87.8 \%)\end{array}$ & $\begin{array}{c}82 \\
(100 \%)\end{array}$ \\
\hline$\chi^{2}$ Value & $\chi 2=5.08$ & $\mathrm{P}=.609$ & $\chi 2=8.1$ & $\mathrm{P}=.004$ & $\chi 2=5.95$ & $\mathrm{P}=.015$ & - \\
\hline \multicolumn{8}{|c|}{ (2) AGE AND GI BENEFITS } \\
\hline Young & $\begin{array}{l}11 \\
(15.5 \%)\end{array}$ & $\begin{array}{l}60 \\
(84.5 \%)\end{array}$ & $5(7 \%)$ & $66(93 \%)$ & $\begin{array}{c}10 \\
(14.1 \%)\end{array}$ & $\begin{array}{c}61 \\
(85.9 \%)\end{array}$ & $\begin{array}{c}71 \\
(86.6 \%)\end{array}$ \\
\hline Old & $0(0 \%)$ & $11(100 \%)$ & $0(0 \%)$ & $11(100 \%)$ & $0(0 \%)$ & $11(100 \%)$ & $11(13.4 \%)$ \\
\hline TOTAL & $11(13.5 \%)$ & $\begin{array}{l}71 \\
(86.5 \%)\end{array}$ & $5(6.1 \%)$ & $\begin{array}{c}77 \\
(93.9 \%)\end{array}$ & $\begin{array}{c}10 \\
(12.2 \%)\end{array}$ & $\begin{array}{c}72 \\
(87.8 \%)\end{array}$ & $\begin{array}{c}82 \\
(100 \%)\end{array}$ \\
\hline$\chi^{2}$ Value & \multicolumn{6}{|c|}{ (3) TYPE OF WORK } & - \\
\hline Government & $2(7.40 \%)$ & $\begin{array}{l}25 \\
(92.6 \%)\end{array}$ & $0(0 \%)$ & $27(100 \%)$ & $1(3.7 \%)$ & $\begin{array}{c}26 \\
(96.3 \%)\end{array}$ & $\begin{array}{c}27 \\
(23.9 \%)\end{array}$ \\
\hline Private & $9(16.4 \%)$ & $\begin{array}{l}46 \\
(83.6 \%)\end{array}$ & $\begin{array}{c}5 \\
(9.10 \%)\end{array}$ & $\begin{array}{c}50 \\
(90.9 \%)\end{array}$ & $9(16.3 \%)$ & $\begin{array}{c}46 \\
(83.7 \%)\end{array}$ & $\begin{array}{c}55 \\
(67.1 \%)\end{array}$ \\
\hline TOTAL & $11(13.5 \%)$ & $\begin{array}{l}71 \\
(86.5 \%)\end{array}$ & $\begin{array}{c}5 \\
(6.10 \%)\end{array}$ & $77(93.9 \%)$ & $10(12.2 \%)$ & $\begin{array}{c}72 \\
(87.8 \%)\end{array}$ & $\begin{array}{c}82 \\
(100 \%)\end{array}$ \\
\hline$\chi^{2}$ Value & $\chi 2=.549, \mathrm{P}=$ & 459 & $\chi 2=3.2$ & , $\mathrm{P}=.07$ & $\chi 2=6.50$ & $\mathrm{P}=.011$ & - \\
\hline \multicolumn{8}{|c|}{ (4) EXPERIENCES IN PROFESSIONAL GI DOMAIN } \\
\hline $\begin{array}{c}\text { Less } \\
\text { experienced }\end{array}$ & $\begin{array}{l}11 \\
(14.7 \%)\end{array}$ & $\begin{array}{l}64 \\
(85.3 \%)\end{array}$ & $4(5.3 \%)$ & $\begin{array}{c}71 \\
(94.7 \%)\end{array}$ & $\begin{array}{c}10 \\
(13.3 \%)\end{array}$ & $\begin{array}{c}65 \\
(86.7 \%)\end{array}$ & $\begin{array}{c}75 \\
(91.5 \%)\end{array}$ \\
\hline $\begin{array}{c}\text { More } \\
\text { experienced }\end{array}$ & $0(0 \%)$ & $7(100 \%)$ & $\begin{array}{c}1 \\
(14.3 \%)\end{array}$ & $6(85.7 \%)$ & $0(0 \%)$ & $7(100 \%)$ & $7(8.5 \%)$ \\
\hline TOTAL & $11(13.5 \%)$ & $\begin{array}{l}71 \\
(86.5 \%)\end{array}$ & $5(6.1 \%)$ & $\begin{array}{c}77 \\
(93.9 \%)\end{array}$ & $\begin{array}{c}10 \\
(12.2 \%)\end{array}$ & $\begin{array}{c}72 \\
(87.8 \%)\end{array}$ & $\begin{array}{c}82 \\
(100 \%)\end{array}$ \\
\hline$\chi^{2}$ Value & $\chi 2=0.032, \mathrm{P}$ & $=.857$ & $\chi 2=.04$ & $\mathrm{P}=.833$ & $\chi 2=.033$ & $\mathrm{P}=.856$ & - \\
\hline \multicolumn{8}{|c|}{ (5) EDUCATION AND GI BENEFITS } \\
\hline Diploma & $1(20 \%)$ & $4(80 \%)$ & $2(40 \%)$ & $3(60 \%)$ & $2(40 \%)$ & $3(60 \%)$ & $5(6.1 \%)$ \\
\hline Bachelor & $10(14.3 \%)$ & $60(85.7)$ & $3(4.3 \%)$ & $\begin{array}{c}67 \\
(95.7 \%)\end{array}$ & $8(11.4 \%)$ & $\begin{array}{c}62 \\
(88.6 \%)\end{array}$ & $\begin{array}{c}70 \\
(85.4 \%)\end{array}$ \\
\hline Postgraduate & $0(0 \%)$ & $7(100 \%)$ & $0(0 \%)$ & $7(100 \%)$ & $0(0 \%)$ & $7(100 \%)$ & $7(8.5 \%)$ \\
\hline TOTAL & $11(13.5 \%)$ & $\begin{array}{c}71 \\
(86.5 \%)\end{array}$ & $\begin{array}{c}5 \\
(6.10 \%)\end{array}$ & $77(93.9 \%)$ & $10(12.2 \%)$ & $\begin{array}{c}72 \\
(87.8 \%)\end{array}$ & $\begin{array}{c}82 \\
(100 \%)\end{array}$ \\
\hline$\chi^{2}$ Value & $\chi^{2}=1.79$ & $\mathrm{P}=.181$ & $\chi 2=5.9$ & $\mathrm{P}=.015$ & $\chi 2=4.8$ & $\mathrm{P}=.027$ & - \\
\hline
\end{tabular}


Table 4 segment 1 reported the $\chi 2$ test for practitioners' gender. The $\chi 2$ result indicates that gender makes a significant difference concerning social and environmental benefit $(\mathrm{p}<0.05)$, while it does not make a considerable difference for economic benefits $(\mathrm{p}>0.05)$. The table also shows that all-female $(\mathrm{N}=19)$ had high beliefs $(\overline{\mathrm{x}}>3)$ concerning the economic, social and environmental benefits of GI. Analysis on segment 2 reported the $\chi 2$ test for age. The $\chi^{2}$ result indicates that age has no statistical relationship (p $>0.05$ ) to all types of attitude (economic, social and environmental). The table also shows that all old practitioners $(\mathrm{N}=11)$ had high belief $(\overline{\mathrm{x}}>3)$ for economic, social and ecological benefits. Analysis on segment 3 reported the $\chi 2$ test for a place of work. The $\chi 2$ result indicates that the type of agency makes a significant difference for environment benefit $(p<0.05)$, while it does not make a substantial difference concerning economic and social benefits $(p>0.05)$. The table also shows that all government practitioners $(\mathrm{N}=27)$ had high beliefs $(\overline{\mathrm{x}}>3)$ about the social benefits of GI.

Analysis on segment 4 shows that practitioners' experiences have not any statistical relationship ( $\mathrm{p}>$ 0.05 ) with aspect to all types of attitude (economic, social and environmental). The table also shows that all high experienced practitioners $(\mathrm{N}=7)$ had high beliefs $(\overline{\mathrm{x}}>3)$ for the economic and environmental benefits of GI. The final segment shows that education does not make a significant difference concerning economic benefit ( $\mathrm{p}<0.05$ ), while it makes substantial about social and economic benefits $(p>0.05)$. The table also shows that all postgraduate practitioners $(N=7)$ had high belief $(\bar{x}>3)$ in all GI benefits economic, social and environmental).

\section{Conclusion}

Analyzing attitude among the practitioners on the practice of GI shows five main findings. First, the level of attitude among practitioner was positive at $\bar{x}=3$. 98. the most popular Attitude (RII $=89.6 \%$ ) was awarded to the role of GI to reduces life and work stress. In contrast, the lowest popular Attitude (RII $=68.6 \%$ ) was awarded to the role of GI to reduce the noise of the city. Second, the highest type of attitude was awarded to the environment attitude with a mean $=4.11$. At the same time, the lowest type of attitude was awarded to economic attitude with a mean $=3.91$. third, all-female, old and government practitioners have a positive attitude. Similarly, all those with high GI professional domain experience and those having postgraduate degrees also have a positive attitude. Fourth the factor of gender makes a significant difference concerning social and environmental attitude. Similarly, the type of agency makes a significant difference concerning environmental attitude, while education makes a significant difference for social and environmental attitude. Fifth practitioners' gender has positive significant their attitude toward having GI in Mukalla city $(\beta 4=.209$; $\mathrm{t}$-value $=2.000 ; \mathrm{p}<0.05)$. similarly, practitioners' knowledge has positive and significant influenced their attitude toward having GI in Mukalla city ( $\beta 7=$ $.295 ; \mathrm{t}$-value $=2.830 ; \mathrm{p}>0.01$ ).

\section{References}

Al-Alimi, A. K. A. A., Nasher, G. S. A., Saban, M. S., \& Sad, R. H. B. (2013). Water Quality Degradation of Al-Mukalla Groundwater Aquifer/Yemen.

Al Khulaidi, A. W. A. (2006). Environmental and human determinates of vegetation distribution in the Hadhramaut region, Republic of Yemen.

Alabi, M. O., \& Christian, E. I. (2013). Street Tree Canopy Cover Variation Effects on Temperature in Lokoja, Nigeria. Journal of Agriculture and Environmental Sciences, 2(2), 25-31.

Al-Maashi, T. A. (1998). Vernacular domestic architecture of Mukallah, Yemen. Texas Tech University.

Asadian, Y., \& Weiler, M. (2009). A new approach in measuring rainfall interception by urban trees in coastal British Columbia. Water Quality Research Journal, 44(1), 16-25.

Benedict, M. A., \& McMahon, E. T. (2002). Green infrastructure: smart conservation for the 21st century. Renewable Resources Journal, 20(3), 12-17.

Beyer, K. M. M., Kaltenbach, A., Szabo, A., Bogar, S., Nieto, F. J., \& Malecki, K. M. (2014). Exposure to neighborhood green space and mental health: evidence from the survey of the health of Wisconsin. 
International Journal of Environmental Research and Public Health, 11(3), 3453-3472.

Chakre, O. J. (2006). Choice of eco-friendly trees in urban environment to mitigate airborne particulate pollution. Journal of Human Ecology, 20(2), 135-138.

Chibrik, T. S., Lukina, N. V, Filimonova, E. I., Glazyrina, M. A., Rakov, E. A., Maleva, M. G., \& Prasad, M. N. V. (2016). Biological recultivation of mine industry deserts: Facilitating the formation of phytocoenosis in the middle Ural region, Russia. In Bioremediation and Bioeconomy (pp. 389418). Elsevier.

Cirillo, C., \& Podolsky, L. (2012). Health, Prosperity and Sustainability: The Case for Green Infrastructure in Ontario. Green Infrastructure Ontario Coalition.

Demuzere, M., Orru, K., Heidrich, O., Olazabal, E., Geneletti, D., Orru, H., Bhave, A. G., Mittal, N., Feliu, E., \& Faehnle, M. (2014). Mitigating and adapting to climate change: Multi-functional and multi-scale assessment of green urban infrastructure. Journal of Environmental Management, 146, $107-115$.

Deng, J., Arano, K. G., Pierskalla, C., \& McNeel, J. (2010). Linking urban forests and urban tourism: a case of Savannah, Georgia. Tourism Analysis, 15(2), 167-181.

Dietz, M. E. (2007). Low impact development practices: A review of current research and recommendations for future directions. Water, Air, and Soil Pollution, 186(1-4), 351-363.

Du Toit, M. J., Cilliers, S. S., Dallimer, M., Goddard, M., Guenat, S., \& Cornelius, S. F. (2018). Urban green infrastructure and ecosystem services in sub-Saharan Africa. Landscape and Urban Planning, 180, 249-261.

Foster, J., Lowe, A., \& Winkelman, S. (2011). The value of green infrastructure for urban climate adaptation. Center for Clean Air Policy, 750(1), 1-52.

Gallet, D. (2011). The Value of green infrastructure: a guide to recognizing its economic, environmental and social benefits. Proceedings of the Water Environment Federation, 2011(17), 924-928.

Girma, Y., Terefe, H., Pauleit, S., \& Kindu, M. (2019). Urban green infrastructure planning in Ethiopia: The case of emerging towns of Oromia special zone surrounding Finfinne. Journal of Urban Management, 8(1), 75-88.

Gonzalez-Meler, M. A., Cotner, L., Massey, D. A., Zellner, M. L., \& Minor, E. S. (2016). The environmental and ecological benefits of green infrastructure for stormwater runoff in urban areas.

Hansmann, R., Hug, S.-M., \& Seeland, K. (2007). Restoration and stress relief through physical activities in forests and parks. Urban Forestry \& Urban Greening, 6(4), 213-225.

Hartig, T., van den Berg, A. E., Hagerhall, C. M., Tomalak, M., Bauer, N., Hansmann, R., Ojala, A., Syngollitou, E., Carrus, G., \& van Herzele, A. (2011). Health benefits of nature experience: Psychological, social and cultural processes. In Forests, trees and human health (pp. 127-168). Springer.

Jeanjean, A. P. R., Gallagher, J., Monks, P. S., \& Leigh, R. J. (2017). Ranking current and prospective $\mathrm{NO}_{2}$ pollution mitigation strategies: An environmental and economic modelling investigation in Oxford Street, London. Environmental Pollution, 225, 587-597.

Kemperman, A., \& Timmermans, H. (2014). Green spaces in the direct living environment and social contacts of the aging population. Landscape and Urban Planning, 129, 44-54.

Kim, D., \& Song, S.-K. (2019). The Multifunctional Benefits of Green Infrastructure in Community Development: An Analytical Review Based on 447 Cases. Sustainability, 11(14), 3917.

Kumar, P. (2010). The economics of ecosystems and biodiversity: ecological and economic foundations. UNEP/Earthprint.

Leavitt, M. O. (2007). Department of Health and Human Services. Disaster Medicine and Public Health Preparedness, 1(1), 7. https://doi.org/10.1097/DMP.0b013e3180cac8c7

Li, B., Chen, D., Wu, S., Zhou, S., Wang, T., \& Chen, H. (2016). Spatio-temporal assessment of urbanisation impacts on ecosystem services: Case study of Nanjing City, China. Ecological Indicators, 71, 416-427.

Li, X., Ratti, C., \& Seiferling, I. (2018). Quantifying the shade provision of street trees in urban landscape: A case study in Boston, USA, using Google Street View. Landscape and Urban Planning, $169,81-91$.

Liu, W., Chen, W., \& Peng, C. (2014). Assessing the effectiveness of green infrastructures on urban flooding reduction: A community scale study. Ecological Modelling, 291, 6-14.

Lovell, S. T., \& Taylor, J. R. (2013). Supplying urban ecosystem services through multifunctional green infrastructure in the United States. Landscape Ecology, 28(8), 1447-1463. 
Luan, B., Yin, R., Xu, P., Wang, X., Yang, X., Zhang, L., \& Tang, X. (2019). Evaluating Green Stormwater Infrastructure strategies efficiencies in a rapidly urbanizing catchment using SWMMbased TOPSIS. Journal of Cleaner Production, 223, 680-691.

Luttik, J. (2000). The value of trees, water and open space as reflected by house prices in the Netherlands. Landscape and Urban Planning, 48(3-4), 161-167.

Maas, J., Verheij, R. A., Groenewegen, P. P., De Vries, S., \& Spreeuwenberg, P. (2006). Green space, urbanity, and health: how strong is the relation? Journal of Epidemiology \& Community Health, 60(7), 587-592.

MacKinnon, K., Sobrevila, C., \& Hickey, V. (2008). Biodiversity, climate change, and adaptation: nature-based solutions from the World Bank portfolio. The World Bank.

Majumdar, S., Deng, J., Zhang, Y., \& Pierskalla, C. (2011). Using contingent valuation to estimate the willingness of tourists to pay for urban forests: A study in Savannah, Georgia. Urban Forestry \& Urban Greening, 10(4), 275-280.

Mukalla: Gateway to the Hadramout. (n.d.). Assessment.

Peters, K., Elands, B., \& Buijs, A. (2010). Social interactions in urban parks: stimulating social cohesion? Urban Forestry \& Urban Greening, 9(2), 93-100.

Poe, M. R., McLain, R. J., Emery, M., \& Hurley, P. T. (2013). Urban forest justice and the rights to wild foods, medicines, and materials in the city. Human Ecology, 41(3), 409-422.

Rahman, S. R. A., Ahmad, H., \& Rosley, M. S. F. (2013). Green roof: Its awareness among professionals and potential in Malaysian market. Procedia-Social and Behavioral Sciences, 85, 443-453.

Randolph, J. (2004). Environmental land use planning and management. Island Press.

Roe, J. J., Thompson, C. W., Aspinall, P. A., Brewer, M. J., Duff, E. I., Miller, D., Mitchell, R., \& Clow, A. (2013). Green space and stress: evidence from cortisol measures in deprived urban communities. International Journal of Environmental Research and Public Health, 10(9), 4086-4103.

Roe, M., \& Mell, I. (2013). Negotiating value and priorities: evaluating the demands of green infrastructure development. Journal of Environmental Planning and Management, 56(5), 650-673.

SG. (2012). Making the most of communities' natural assets: green infrastructure. Scotland: Scottish Government Edinburgh.

Thompson, C. W., Roe, J., Aspinall, P., Mitchell, R., Clow, A., \& Miller, D. (2012). More green space is linked to less stress in deprived communities: Evidence from salivary cortisol patterns. Landscape and Urban Planning, 105(3), 221-229.

Tzoulas, K., Korpela, K., Venn, S., Yli-Pelkonen, V., Kaźmierczak, A., Niemela, J., \& James, P. (2007). Promoting ecosystem and human health in urban areas using Green Infrastructure: A literature review. Landscape and Urban Planning, 81(3), 167-178.

United Nations. (2011). World Ubanization Prospects: the 2011 Revision. New York: Depaetment of Economic and Social Affairs.

Vasilevska, M., \& Vasilevska, L. (2019). Benefits of synergy of urban green infrastructure and integrated stormwater management approaches: theoretical perspective and examples from Vienna. Facta Universitatis, Series: Architecture and Civil Engineering, 17(2), 145-157.

Vitousek, P. M., Mooney, H. A., Lubchenco, J., \& Melillo, J. M. (1997). Human domination of Earth's ecosystems. Science, 277(5325), 494-499.

Wolf, K. L., \& Robbins, A. S. T. (2015). Metro nature, environmental health, and economic value. Environmental Health Perspectives, 123(5), 390-398.

Xiao, X. D., Dong, L., Yan, H., Yang, N., \& Xiong, Y. (2018). The influence of the spatial characteristics of urban green space on the urban heat island effect in Suzhou Industrial Park. Sustainable Cities and Society, 40, 428-439.

Youngquist, T. D. (2009). What is green infrastructure? An evaluation of green infrastructure plans from across the United States.

Zimmerman, M. J., Waldron, M. C., Barbaro, J. R., \& Sorenson, J. R. (2010). Effects of low-impactdevelopment (LID) practices on streamflow, runoff quantity, and runoff quality in the Ipswich River Basin, Massachusetts: A summary of field and modeling studies. US Geological Survey Circular, $1361,40$. 